\title{
The role of pro-reform civil society in Serbia's accession to the EU: oppositional discourses, watchdog role and EU advocacy
}

\author{
Nina Markovic Khaze \\ Australian National University \\ nina.markovic@anu.edu.au
}

\begin{abstract}
This article critically assesses the role of pro-reform and pro-EU civil society in the process of Serbia's accession to the European Union (EU). Civil society (the so-called non-government or third sector) has played a fundamental role in the democratisation of former Communist countries, including in the Western Balkans where the majority of aspirant EU members still reside. Serbia's democratic transformation began soon after its regime-change occurred on 5 October 20oo. This country's process of democratic consolidation is ongoing and is strongly supported by pro-EU civil society actors who are key drivers of Europeanisation. Civil society organisations and actors have increased general knowledge about the quality of democratic reforms in Serbia and brought in technical expertise which has assisted Serbian society to align better with the EU's acquis. Specific examples of civil society's activism in this article will demonstrate some unique characteristics of Serbia's third sector. Its evolution from an anti-war movement and loosely connected individuals and citizens' associations in the 1990 s to becoming a major advocate of EU membership in Serbia and a partner to the Serbian Government on EU accession is worthy of further academic research and analysis.
\end{abstract}

Keywords: accession, Serbia-EU relations, civil society, NGOs, European integration

\section{Introduction}

The model of permanent mobilisation that was demonstrated during the mass protests [in Serbia] consists of: active and spontaneous participation of individuals and groups, connected by the same ends but not the same organisation; reaching of a consensus on the important questions; open communication without taboo topics; generalisation of requests so that only those requests that are in the public good will withstand; the high level of critical thinking towards the leaders; innovation, fast learning, solidarity and a high level of care for one's fellow participants.

Zoran Đinđić, Borba, 8 August 1997

Pro-reform civil society has been indispensable for Serbia's democratisation process, as 'part of society that stands opposed to the [established] political structure' (Gellner, 1994, p. 56). Its main drivers have been strongly supportive of Serbia's alignment with the acquis of the European Union (EU) and European integration more generally. 
There are three main roles that civil society has fulfilled since Serbia's regime-change in late 2000: the role of maintaining oppositional political discourses, the watchdog role over the government's performance in key areas of reform, and the role of EU advocacy. This paper will examine in detail each of these roles in Serbia's constantly changing political, social and economic climate using the examples of most prominent pro-EU civil society actors. These include, but are not limited to, the non-government organisations (NGOs) such as the European Movement in Serbia, Civic Initiatives, Forum for Ethnic Relations, the Belgrade Fund for Political Excellence and several human rights advocacy groups (such as the Belgrade Centre for Human Rights). These NGOs have a professionalised workforce, relatively stable budgets and continuity in their work with a record of significant achievements.

As a result of the EU's political conditionality towards Serbia, its political discourses became generally split between the pro-EU and anti-EU camps (Pejic, 2010). Members of the latter group have generally advocated adopting either an anti-Western and proRussian stance in foreign policy, or an independent position without any alignment with key international actors. Due to this dichotomy and, at times, highly emotive debates in mainstream political discourses regarding Serbia's foreign policy orientation, pro-EU civil society has been accused by Serbia's nationalistic parties and anti-EU political groups of being an instrument of 'soft' power of the Western governments (Informativna Služba Dveri, 2017).

Since the focus of this paper is on pro-reform NGOs that are highly relevant for Serbia's European integration process, an analysis of anti-EU NGOs will not be covered here. For information about that aspect of the Serbian NGO sector, see Kostovicova (2006) and Jelena Obradović-Wochnik (2013). This paper will also not offer a chronological study of the development of civil society in Serbia or the legislative instruments that have facilitated better dialogue between the Serbian Government and civil society organisations. It will not specifically examine a comprehensive list of challenges that civil society in Serbia continues to face, such as funding issues, which are an important characterisation of civil society in most post-communist states. Rather, the focus will be on specific roles and functions (with relevant examples) that civil society has fulfilled in order to bring Serbia 'closer to Europe' and advance this country's quest for EU membership.

The article will first discuss the concept of civil society. Then, a survey of Serbia's civil society development and a historical background from the 1990 s era in Serbian politics will assist the reader to better understand the origins of pro-EU civil society activism in Serbia. Oppositional politics and a highly politicised nature of Serbia's civil society and discourses that accompany its activities makes Serbian civil society's experience unique in Southeast European politics for several reasons. Although parliamentary traditions in Serbia can be traced back to the $19^{\text {th }}$ century, it was the very last country in Southeast Europe to topple authoritarianism in 2000, after Croatia (now an EU member) in 1999.

Moreover, pro-Western civil society actors played a specific role during anti-Milosevic protests across Serbia in the 1990 s and 2000, which culminated in Serbia's regime change. In this aspect, Serbian pro-EU civil society organisations have established a mutually supportive relationship with the Western European governments, EU institutions and other Western supporters and donors. Civil society groups and associations formed during that period also mobilised ordinary citizens into bringing 
opposition to the autocratic Milosevic regime to the forefront of daily political discourses and citizens' initiatives. This difficult chapter in Serbian politics provided the context in which some of the oldest and most active pro-EU civil society actors in Serbia were established. Many former NGO and student activists continued to lead their own pro-reform NGOs in post-Milosevic Serbia, such as Sonja Biserko (Helsinki Committee for Human Rights in Serbia, established in 1994), Sonja Licht (Belgrade Fund for Political Excellence, established in 2003-04) and Natasa Kandic (Humanitarian Law Centre, established in 1991). Kandic was even nominated for the 2018 Nobel Peace Prize by US lawmakers.

In the next section, key areas of civil society's activism in Serbia after 2001 will be discussed. These include efforts to promote reconciliation and peace in the region through various initiatives, as case studies will illustrate. Civil society's watchdog role will be also discussed. The focus of this section will be specifically on the pro-EU elements of Serbia's civil society that have played a vital role in promoting freedom of speech, human rights and freedom of the press. These NGOs have been conducive to the accession negotiations and committed to Serbia becoming a 'good democratic and European citizen' by spreading the values of social inclusion, tolerance and participatory democracy. In Serbia's context, this has meant fulfilling the criteria for EU accession by aligning the country with the EU's acquis, improving regional cooperation with former wartime foes, and fulfilling obligations of international justice by extraditing key war crimes suspects to the International Criminal Tribunal for the Former Yugoslavia in The Hague. Understanding the historical legacy of Serbia's civil society (as discussed in the section below) is fundamental to our understanding of the political challenges which pro-EU civil society's activists have faced and will continue to face in post-Milosevic Serbia.

\section{Historical legacy of the 1990 s era}

\section{Oppositional political discourses, cooperation with political opposition to the Milosevic regime and links with the EU and the West}

According to the famed American political scientist and theorist of democratisation Robert Dahl, key arenas of democracy include the realm of free and fairly conducted elections; universal suffrage and the right to run for public office; responsiveness of government and parties to the voters; the guarantee and protection of the freedom of expression; the existence and free access to alternative information (not controlled by the government); and associational autonomy (Keman, 2018). The right for citizens to organise in autonomous associations outside official government institutions is supported by the acquis of the European Union, and guaranteed through national legal systems of EU members. Article 11 of the Lisbon Treaty stipulates that in the name of coherency and transparency, EU institutions 'shall maintain an open, transparent and regular dialogue with representative associations and civil society', and 'give citizens and representative associations the opportunity to make known and publicly exchange their views in all areas of Union action' (EUR-LEX, 2012). This commitment to civil society by the EU makes it an even stronger imperative that EU candidates develop required legal protections as well as regulative frameworks that would make the work of NGOs safe, supported and truthfully represented.

Furthermore, as part of the accession negotiations, the European Commission has frequently stressed the need for an inclusive and autonomous civil society as a 
precondition for accession. EU accession is an established political route that all new EU members have previously taken. An exception to this rule includes the six founding countries that were interlocked in a different type of inter-governmental bargaining in post-war Europe in order to create new treaties and mechanisms that laid the EU's foundations as a project for peace. Another exception is the case of East Germany, which was the subject of special negotiations and arrangements between West Germany, an EU member, and other EU members. The preparation for EU membership involves the fulfilment of the EU's strict accession criteria, for which major structural, legislative, normative, economic and social reforms are necessary. In the Eastern enlargement of the EU from 2004 to 2007, institutions such as the European Commission have played a key role in empowering civil society in acceding member states (Parau, 2008).

The term 'civil society' is used here to indicate those associations which bring people together to advance a public cause through cooperation (most frequently, but not always, in a volunteering capacity) and independently from official government institutions, one's immediate kinship structures and the market (Versteeg, 2011, p. 3). This concept is laden with multiple meanings and explanations. It denotes an independent, non-profit sector between the government, religious institutions and the family, where individuals engage in social and political activism in the pursuit of shared goals and objectives. Civil society's reporting and activism have had an impact on Serbia's accession process due to key pro-EU civil society organisations' close links (and consultative mechanisms) with the European Commission, which were incrementally developed during the 1990 s era in Serbian politics.

\section{Civil society in the 1990s and 2000: bringing Serbia back to Europe}

Serbia in the 1990 s was on the opposite trajectory from the majority of Europe's postcommunist countries, but it was not the only nation to face a delayed transition (Petrovic, 2013, p. 24). While the majority of these countries benefitted from generous transition programs (which assisted the growth of their civil society sector), signed 'Europe Agreements', began creating a market economy and commencing preliminary accession negotiations, Serbia underwent a period of authoritarianism coinciding with a sharp economic decline, dramatic rise in corruption, poverty and hyperinflation the consequences of which are still felt today. As Italian-Serbian political economist Milica Uvalic pointedly observed, while anti-communist revolutions in the rest of Europe opened the doors to the outside world, Serbian youth were unable to travel or study abroad, but 'have spent their youth participating in demonstrations, living in poverty, hounded by the authorities to serve in the army, even arrested or beaten for their 'antistate' activities' (Uvalic, 2012, p. 6). Yugoslavia's isolation amid international sanctions also meant it was excluded from financial assistance programs by the EU, the World Bank and other multilateral institutions, which have fundamentally contributed to the emergence of a market economy and participatory democracy in other post-communist states of East Central and South-East Europe. This dire political, social and economic climate was one in which Serbia's pro-EU civil society activism was born.

Serbia in the early 1990 s was ruled by the authoritarian regime of Slobodan Milosevic, who came to power in 1986 as the regional President of Serbia's Communist Party. He was also the founding President of the Socialist Party of Serbia (established in 1990). 
Milosevic was elected as the first President of post-communist Serbia from 1991 until 1997, and as the third President of the Federal Republic of Yugoslavia (which consisted of the Serbian and Montenegrin republics) from 1997 to 2000. The nature of his domination over Serbian politics has been variously described as 'autocratic', 'populist', nepotistic, corrupt, aggressive and coercive (Djukić, 2001). His government's attitude towards pro-EU NGOs was negative and suppressive, with official political discourses aiming to discredit them by describing NGOs as foreign agents, radical, subversive, anti-nationalist in character and part of a global conspiracy against Serbia. This image of pro-EU NGOs acting as an instrument of soft power by Western governments has never disappeared from Serbia's political, academic and media scene, indicating a disregard of the value of civil society's contributions to Serbia's transition from authoritarianism to democracy (Kresovic, 2016).

Interestingly for the students of protest movements, prior to Yugoslavia's disintegration, Slobodan Milosevic led the so-called 'anti-bureaucratic' revolution in the late 1980s, which was in fact a series of purges against liberalising tendencies across Yugoslavia's political spectrum. Street protests called 'Rallies of truth' by Milosevic's supporters were initiated around the time of pro-independence rallies in Kosovo by ethnic Albanians. They were directed against the moves towards greater autonomy within Serbia's provinces of Vojvodina in the North and Kosovo in the South. By late 1988, street protests spread to more than thirty towns across Serbia. One rally alone in November 1988 in Belgrade gathered several hundred thousand people (The Washington Post, 1988). Milosevic then was instrumental in a change of government in Montenegro, replacing it with his own political allies. The domestic 'success' of his political project was reflected in Serbia's constitutional changes, a reversal of reforms within the political system, and mass arrests of his political opponents. Milosevic would use similar tacticto consolidate his power in Serbia during the 1990 and suppress civil society activists using media, propaganda, and security services against any alternative vision of Serbia's political system (Human Rights Watch, 2000).

Anti-Milosevic mass protests in Belgrade organised by the opposition and student organisations on 9 and 11 March 1991 were brutally supressed by the state's security apparatus, which was reported by international media and criticised by leading international human rights organisations. Amnesty International noted that several hundred student protestors were arrested. It reported that 'students who had been arrested said that they were taken to a police station and made to run the gauntlet, with police officers beating them with truncheons' (Amnesty International, 1992, p. 281). Milosevic accused the protesters of being 'puppets of the West', and for supporting those who 'wanted to take back Serbia to a vassal state', alluding to the Ottoman times (Engelberg, 1991). Opposition media sources were gradually suppressed; civil society became another casualty of that era due to the clampdown by the Yugoslav authorities.

Many liberal-minded academics and activists left Yugoslavia as Milosevic was cementing his grip on power and in protest to his domestic and regional policies. Key opposition leaders, including the nationalist writer turned politician Vuk Draskovic and the Western-minded liberal and philosopher also turned politician Zoran Djindjic, eventually turned to seeking support outside Serbia for their cause. For the first time since socialist Yugoslavia renounced the monarchy in the 1940s, British-born and raised Serbian Crown Prince Aleksandar Karađorđević landed in Belgrade to support an opposition rally in July 1992 which called for Milosevic's resignation (Belgrade City 
Council, 2018). This was the time when one of the oldest and most influential pro-EU organisations in Serbia was established, which, as discussed below, continues to have a positive impact on Serbia's accession negotiations.

The European Movement in Serbia (Evropski Pokret) was established in November 1992 as a non-government (NGO), non-partisan and non-profit organisation. In 1993, it joined the European Movement International association, which has a long tradition of influence and lobbying in European countries with the goal of promoting European integration (European Movement International, 2018). The mission of this far reaching NGO is to influence public opinion in Serbia and to spread awareness of European integration through public campaigns, educational programs, research reports, participation in academic, political and social forums and international meetings. The organisation supports the vision of a federal Europe, the so-called 'United States of Europe' (Evropski Pokret u Srbiji, 2018a). At the grass-roots level in Serbia, this NGO has supported a network of like-minded NGOs for over 25 years. In recent times, in order to assist with accelerating accession processes for the remaining six polities in the Balkans (which includes Albania, Bosnia-Herzegovina, Macedonia, Montenegro and Serbia alongside Kosovo), the European Movement in Serbia supported the creation of a network of civil society organisations from the Balkan region in order to intensify lobbying efforts and to improve their image inside the EU and thereby lessen opposition to their accession (Radio-Television Serbia, 2016). This example of deeper intra-regional cooperation among civil society networks in the Balkans is congruent with the EU's accession conditionality for better regional cooperation amongst these prospective members, which will be a topic of discussion in the next section of this article.

The European Movement in Serbia has been the key supporter of many EU-oriented initiatives, including education seminars, applied research, academic publications and public campaigns aimed at increasing awareness about the European Union in Serbia (Evropski Pokret u Srbiji, 2018b). One of its most prominent activities in the field of Serbia's EU accession has been executing the 'National Convention on European Union' project (established in 2011) in cooperation with the Serbian Parliament, which was financed by the EU. The idea behind this project was to create a permanent forum for dialogue and knowledge exchanges towards improving Serbia's capacities to join the EU; to monitor legislative reforms and Serbia's EU accession negotiations through thematic expert-led working-groups, and to increase public knowledge of such processes through independent analysis and reporting (National Convention on European Union, 2014a).

This NGO has been also active during election times in calling on Serbian citizens to use their electoral right and vote for democratic parties and President (Tanjug, 2017). It was also a key participant at the roundtable discussions between the Serbian leader (formerly Prime Minister and now President) Aleksandar Vucic and pro-EU NGOs on the topic of Serbia's progress in accession negotiations (Telegraf, 2015). The European Movement in Serbia has consistently been a positive force for Serbia's EU accession, pushing for the values which would help Serbia to become more democratic, inclusive and tolerant as a state and society. However, Serbia's place in Europe during the times of crisis and transformation, including during its transition from communism to autocracy in the early 1990 s and later to democracy after 2000 has been the subject of ongoing academic and policy discussions. Anti-democratic forces in Serbia have presented serious obstacles to the work of Serbian pro-EU civil society actors over the 
years, and will continue to do so as long as the official sanctioning of their actions is not severe enough.

\section{Serbia's civil society building rapport with the West: the emergence of OTPOR}

As a result of its involvement in the violent dismemberment of socialist Yugoslavia, which was Europe's bloodiest conflict since the Second World War, Serbia under Milosevic became a pariah state and a subject of international sanctions and additional European punitive measures. During that period, civil society played a pseudodiplomatic role, bridging Serbia's isolation and reaching out to the European Union as an independent actor at the time of most intense pressure put by the West on Serbia, which was under international sanctions (Lopandić and Minić, 2000, p. 75). One such example was the civil society-led protests of 1996-97 and the protests of 1999 and 2000. They helped bring Serbia closer to Europe politically as links between Serbia's civil society, opposition political parties and student groups were formed. This period of civil society's activism will be discussed in the section below.

The role of maintaining oppositional discourses and supporting political opposition in Serbia and Montenegro was a key area of activism for Serbian pro-EU NGOs in the mid to late 1990s. For some of them, links with the West already existed, as they had been established with support from overseas donors (such as the European Movement in Serbia). The Pro-EU Civic Initiatives (Gradjanske Inicijative) association was established in 1996 by a number of 'prominent civil society activists who were involved in Serbia's anti-war movement and anti-nationalistic democratic opposition'; their method of supporting democratic reforms has been through civic education about citizen rights, democracy, activism and volunteering (Civic Initiatives, 2018). A mission of this NGO, which has become one of the most prominent pro-EU NGOs in the region, is to spread civic and democratic values such as tolerance, solidarity, equal opportunities for all and life-long education. Currently, their two main initiatives include programs for improving capacities of Serbia's civil society and a public policy program.

At the time of its founding, Civic Initiatives became a discussion forum and a vehicle of dissent, bringing together writers, academics, artists and opposition figures who opposed the Milosevic regime. Its de-facto leader and director from 1996 until 2014 was Miljenko Dereta, a prominent film-maker who once stood as an opposition candidate for the Serbian Parliament in the first post-Communist and multi-party elections in 1990 (Civic Initiatives, 2016). The climate in which Civic Initiatives was formed was one of political tension as the Milosevic regime was readying for local and federal parliamentary elections, the outcome of which sparked the largest protest in the history of student-movements in the region.

The results of the local elections in Serbia, which were held in two rounds in November 1996, demonstrated a strong support for opposition candidates in large cities such as Belgrade (capital), Kragujevac and Nis. In the first round of elections, for example, democratic opposition called 'Together' won 70 out of 110 seats in Belgrade. However, the ruling party annulled these results by exerting political pressure on the courts and electoral commission, and a new round of elections was called (Goati, 2001, pp. 74-77). Pro-democracy NGOs condemned the blatant disregard of Serbia's constitutional laws. Reports of widespread electoral fraud and the use of physical violence against 
independent electoral observers at many polling stations across Serbia set off the largest wave of citizen protests of the 1990 s in that region; the protests lasted from November 1996 to March 1997. They were principally led by student organisations, and involved representatives from opposition political parties, academics, writers, artists, lawyers and public servants. They were strongly supported by Serbia's civil society sector and pro-EU NGOs which were collectively advocating for a regime-change through peaceful means.

According to a Serbian law professor Dragica Vujadinovic, the aims of Serbia's mass protests were two-fold. Firstly, they were a demonstration of civil disobedience and a nation-wide revolt against electoral fraud and the Milosevic regime more broadly. Secondly, it was an unequivocal call by the students and civil society actors for the establishment of a "normal, modern state and society, for the change of (an entire political, social and economic) system, and for a radical change of the media environment and political culture' in Serbia (Vujadinović, 2009, p. 2001). In 1998, Vujadinovic was one of the founders of the Alternative Academic Education Network (AAEN), an NGO based in Belgrade. This NGO was established in protest against new government regulations restricting academic freedoms, firing academic workers because of their pro-democratic views and which censored and severely curtailed independent research (Human Rights Watch, 1998). More specifically, the main aim of this network was to provide an alternative educational pathway to students and junior academics and to lay the groundwork for university reform. It received support from the Council of Europe, the Association of European Universities, World Universities, Austria and Germany (Organization for Economic Cooperation and Development, 2003, p. 394).

The student protest wave of the 1996-97 was halted after the Milosevic regime nominally met some of the protesters' demands. However, this was short-lived as new draconian laws were introduced that restricted the freedom of speech and press as well as academic freedoms, especially those introduced in May 1998 (Radio Free Europe, 1999). AAEN then became increasingly popular amongst pro-democracy students and academics as it provided a forum for discussion of European laws, values and institutional practices as well as democratic processes more generally - all topics that were restricted by the Serbian Government. Civil society associations like AAEN were the primary vehicle during those turbulent times for educating the Serbian public about the EU, thereby also fulfilling the very important role of de facto EU advocacy.

Despite the fact that the 1996-97 protests did not result in a regime-change, civil society's activism against the authoritarian government substantially increased. A new organisation called Otpor (meaning 'Resistance' in English) established in October 1998, emerged as a herald of civil society's activism (Nikolayenko, 2013, p. 147). Otpor's organisers (the most prominent being Ivan Marovic and Srdja Popovic) obtained support and training through USAID, the National Endowment for Democracy (NED) and gathered political support from other Western governments (Brandt, 2011). Albert Cevallos from the US Institute of Peace wrote that by 2000, U.S. assistance to Otpor and other pro-democracy groups in Serbia was around \$25 million (Cevallos, 2001, p. 5).

Otpor had a unique organisational structure as it did not feature a single leader, who could have been easily targeted (and possibly silenced) by government agencies, but a horizontal network of activists all across Serbia (Sombutpoonsiri, 2012). It also 
received support from Serbia's student networks abroad, in particular the European and U.S. branches of the Organization of Serbian Students Abroad (Organizacija Srpskih Studenata u Inostranstuu ( OSSI)), which was an NGO that was lobbying Western governments to back the civil society's-led goal of peaceful regime-change in Serbia. This NGO which had branches world-wide (and which included a Harvard student, Vuk Jeremic, who later became Serbia's Foreign Minister in a pro-EU, democratic government), was formed in mid-1997 in solidarity with Serbian students who led the 1996-97 mass protests (Kulish, 2010).

As Otpor's membership base grew (from an urban student group to a national movement), its links with the international aid community also expanded. Kuzio observed that the training of civil society organisations and youth movements in Serbia, which was undertaken with Western technical and financial assistance, formed part of the success 'recipe' for Serbia's regime-change (Kuzio, 2006). Spierri estimates that Otpor received some $\$ 390,000$ in funding from USAID, NED and the International Republican Institute (IRI) to open over twenty offices across Serbia, train activists and pay for the publication of printed material that was widely distributed (Spoerri, 2015, p. 87). OSSI specifically supported Serbia's regime-change by sending telecommunications equipment from abroad to activists in Serbia, where mobile and satellite phone technology was difficult to access and replace once confiscated by the security services (Markovic, 2014, p. 220).

In light of these new activities in the field of civil society's activism in Serbia, the European Commission, alongside other European institutional and state actors, decided to more actively lend the EU's support to democracy promotion in Serbia. By then the European Parliament had already established the European Initiative for Human Rights and Democracy, a world-wide program to support civil society development and vulnerable groups, and to address 'differentiated human rights and democracy objectives at international and national level' (EU Delegation in Serbia, 2018). The programs 'generally had to be implemented in partnership with NGOs and international organisations', which was made easier for Serbian civil society once Otpor was formally organised (EUR LEX, 2007). The European Commission therefore supported democratic reforms in Serbia separately from the United States-led efforts to strengthen civil society in Serbia through programs that contributed to the emergence and maintenance of OTPOR's activities.

A consensus to oust Milosevic in the West and among Serbian opposition parties and political groups after Otpor's emergence brought a lot of attention to pro-democracy efforts and initiatives in Serbiat providing the foundation for the development of many pro-EU NGOs after the revolution on 5 October 2000. According to some estimates, there were over 2,000 civil society organisations registered in Serbia in 2001, with their numbers soaring to over 15,000 only a decade later (Media Centre Belgrade, 2011). In June 2000, the European Council's Presidency provided an unequivocal statement which demonstrates the link between Serbia's civil society and the EU's support for change:

The European Council supports the civil society initiatives as well as the democratic forces in Serbia in their struggle to achieve this goal [of EU accession] and urges them to stay united and reinforce their cooperation. (European Parliament 2000) 
Protests in Serbia against Milosevic restarted on a daily basis in September 2000, and on 29-30 September many protesters and members of the Alliance for Change were brutalised by the police (Belgrade City Council, 2018). Citizen dissent culminated with a mass revolt after Milosevic did not concede his presidential electoral defeat. It led to a negotiated regime change on 5 October 2000 between the Serbian opposition and security forces, with Milosevic finally stepping down. Opposition' candidate Vojislav Kostunica, a moderate nationalist who had effectively won the elections, became Serbia's President and took Serbia (as part of the Federal Republic of Yugoslavia) back into the United Nations on 31 October (United Nations, 2000). Democratic parties won a landslide victory in the December 2000 parliamentary elections, which was hailed internationally as a new era for the Balkans. This ushered in a fresh start in the relations between the EU and Serbia, as well as between the Serbian Government and pro-EU civil society, whose numbers and networks grew exponentially in Serbia as the next section will discuss.

The EU's ties to the Serbian opposition, to civil society, and with Serbia's first democratic government of Prime Minister Zoran Djindjic that was formed in early 2001have been instrumental for the reestablishment of positive EU-Serbia relations after the regime change d. In June 2002 in Belgrade, at the opening of the Second International Convention of NGOs from Central Europe, ex-Soviet area and Turkey, the Prime Minister thanked civil society for their important role that had contributed to Serbia's regime change on 5 October 2000, further noting that the advancement of civil society in Serbia was 'a precondition and the goal' of any further economic development (Beta, 2002). Djindjic, who was a champion of democracy, Serbia's return to Europe and speedy EU membership, was assassinated only two years later, following his decision to send Milosevic to the International Criminal Tribunal for the former Yugoslavia in The Hague despite the Serbian President's public dissent (British Broadcasting Corporation, 2001). It was a chilling reminder to all pro-EU groups and NGOs in Serbia that their struggle for recognition and democratic reform may be far from over.

\section{Profile and main activities of civil society in post-Milosevic Serbia}

Since Serbia's regime-change, the European Union has been the most active promoter of democracy and civil society's development in this country, recognising that only a holistic approach to democratic transformation can bring about true democratic reforms, by the government from 'above' and from 'below' by civil society acting as a monitor and watchdog of the government's performance in key areas of reform. Nonholistic method involves investing only in reforming the so-called procedural aspects of democracy, which includes political parties, electoral politics and the reform of government institutions. However, this is inadequate as transformation from below must include grassroots-level groups and organisations. This can only be achieved through a complementary approach that includes civil society's development and sustainability. Other partners of the EU in this 'mission' include individual aid and development agencies of member states (in particular Germany and Sweden), non-EU countries such as Switzerland and Norway, as well as international organisations (such as the European Bank for Reconstruction and Development and the World Bank) and government bodies such as the United States' overseas development assistance agency, USAID. Collectively, these donors have provided millions in funding assistance for various democratisation initiatives, amongst which were also funds for the development of civil society organisations, capability, training and networks. It was 
crucially important for donors and established NGOs to raise awareness about the importance of civil society for Serbia's reforms, because in many post-Communist countries, citizens were frequently shying away from volunteerism as a result of past forced membership of the Communist party and many of its organisations.

Romanian scholars Bogdan Voicu and Malina Voicu have found that being from an excommunist country 'has a negative impact on the level of volunteering.' However, they also found that Westernisation because of European integration processes and democratisation have opened up new avenues for volunteering in Europe's former Communist states, bringing a 'revival of the associative life'. As a result, there have been increasing trends of volunteering in the majority of those countries after the first decade of democratic transition (Voicu and Voicu, 2009, p. 540). Serbia exhibits a similar trend, with a majority of pro-reform NGOs being formed after 2000, with an increasing trend particularly noted after 2010 -- as will be discussed in more detail below (Gradjanske Inicijative, 2017).

\section{Mapping the NGO sector in Serbia}

It is difficult to quantify the total external investment in NGO development in Serbia, as there was no single institution or method responsible for distributing those funds for the development of civil society specifically. As a recipient of international postconflict reconstruction and development funds, Serbia received some EUR 8.9 billion between 2001 and 2012 in international ODA, with an annual funding of approximately EUR 800 million. The actual annual allocations varied as a result of global economic climate and domestic conditions, with an average of EUR 275 million per year after 2012 until 2017 (Gradjanske Inicijative, 2017, p. 3). This indicated a trend of phasing out of donor assistance to Serbia after 2012, but this seemed to have little effect on the increasing number of NGOs in Serbia after 2010.

As a result of increased donor engagement and interest in Serbia after 2000, the number of NGOs flourished. As of May 2017, there were '29,926 associations, 68 foreign associations, 761 endowments and foundations and 25 foreign endowments and foundations branch offices' registered in Serbia, according to the Serbian Business Registers Agency. The majority of these entities (72 per cent) were formed after 2000 (of which 43 per cent were formed after 2010), 10 per cent were established between 1990 and 2000, and 18 per cent before 1989. The NGO sector employed around 6,600 people in Serbia on a full-time basis in 2014, with at least double that number further being employed on a part-time or contract basis (Gradjanske Inicijative, 2017, p. 1112). The majority of full-time employees are highly skilled. NGOs in Serbia are mostly concentrated in larger urban areas, with capital Belgrade and the Vojvodina district being home to some 64 per cent of the total number of NGOs. Around one quarter has been involved in some form of international cooperation. The majority of NGOs which receive sustained overseas donor assistance are predominantly involved in Projectbased work, resulting in a high degree of specialisation and even advisory capacity of some NGOs vis-à-vis the Serbian government (such as the Belgrade Fund for Political Excellence).

The regulatory environment in which civil society has been operating also gradually improved as Serbia progressed along its path of democratic reform. After many years in the making, the Serbian Government established the Office for Cooperation with Civil Society in 2010, an office to specifically promote civil society's development () and 
to work closely with the European Integration Office (established in 2004). While there are many areas of reform still needed for Serbia's civil society to be strengthened further (for example with incentives through tax concessions for donations towards civil society organisations), the Serbian Government is today a major donor to civil society organisations, with its annual funding exceeding 3 million euros. For example, in 2012, the Serbian Government provided around 9 million euros to civil society, more than double the amount of the previous year (Office for Cooperation with Civil Society, 2014, pp. 18-19). Since November 2012, the Office for Cooperation with Civil Society received a boost in funding from the European Union, which could partially explain this substantial increase (Office for Cooperation with Civil Society 2014: 22). Civic Initiatives NGO has been, for instance, amongst the largest recipients of the government's assistance, receiving some EUR 1 million in total funding from 2006 until 2014 (Popadic, 2015).

After 2009 when Serbia official applied for EU membership key areas of of NGO activity were addressed. They included topics such as the dialogue between the Serbian Government and NGO sector, promotion of good neighbourly relations, protection of media freedoms, urging resolution of the Kosovo issue and the promotion of human and minority rights (Wunsch, 2015, p. 454). Some of these areas of activity will be specifically discussed in the next sections as illustrative examples of civil society's contributions to Serbia's EU accession after Milosevic.

\section{The Serbian Government's dialogue with civil society: the case of the annual Belgrade Security Forum}

After 2000, several prominent pro-EU organisations became highly professionalised, skilled workspaces also attracting Serbian diaspora and Serbian students educated overseas. Some of the oldest and most outspoken of these organisations contribute to Serbia's accession process by organising high-profile annual forums that probe various aspects of Serbia-EU relations, while also observing and reporting on the nature and quality of democratic reforms in Serbia (a 'watchdog' role). A useful example is the annual Belgrade Security Forum (BSF), which has emerged as a key dialogue space between academics, policy-makers, public servants and civil society organisations (Belgrade Security Forum, 2018). This event, which attracts more than 500 participants, is organised by a number of prominent Belgrade-based pro-EU civil society organisations with support from external donors. Most prominent NGO donors include the Belgrade Centre for Security Policy (founded in 1997), the European Movement in Serbia (founded in 1992), and the Belgrade Fund for Political Excellence (founded in 2003). BSF has become one of the most prominent regional forums dealing with security issues, European accession and challenges to democracy in the region and Europe more broadly.

In 2016, the sixth BSF is remembered because of a direct encounter in a forum between the Prime Ministers of Serbia and Albania, Aleksandar Vucic (now President of Serbia) and Edi Rama respectively, which was moderated by British Balkan specialist Misha Glenny. Serbian NGOs, in particular the Belgrade Fund for Political Excellence, initiated this meeting. It took place during a time of high tensions between Serbia and Kosovo, which has close diplomatic and political relations with Albania. According to Sonja Licht, founder and President of the Belgrade Fund for Political Excellence, the way in which the Vucic-Rama's dialogue was being conducted represented a step ahead for the entire Balkan region, which is characterised 'not only as a space for conflict but 
also as a space with a lack of ability to conduct dialogue' (Gace and Jovanovic, 2016). Licht observed that Vucic and Rama engaged in a frank and open discussion at the BSF as they responded in an intelligent way to each other's arguments (despite having opposing views on almost every major regional issue). Following the end of the forum, both leaders were able to continue their dialogue in the town of Nis and have an official government-to-government meeting, a direct result of their encounter at the BSF.

The annual BSF is, therefore, an example of how civil society's activism and inter-NGO cooperation in Serbia has contributed to the establishment of a regular dialogue mechanism between Serbian pro-reform civil society and government institutions on the topic of regional and global challenges to Serbia's EU accession. It has also made some breakthroughs in Serbia's relations with its neighbours, as this prestigious forum provides a 'safe space' where second-track dialogue can take place in an honest atmosphere between equals and in a non-prejudiced way. Civil society's specific role as a watchdog in overseeing Serbia's relations with its neighbours, especially those with which bilateral issues emerged, will be discussed next.

\section{Regional cooperation and good neighbourly relations as a precondition for accession: civil society's role}

According to the European Commission, one of the key prerequisites for EU membership is the adoption of EU value-system, which inter alia includes the promotion, fostering and maintenance of 'good neighbourly relations'. This criterion was set up specifically for the countries in Southeast Europe, the former Yugoslavia and Albania (sometimes collectively referred to as the 'Western Balkans') under the Stabilisation and Association process (SAP). The EU adopted SAP in June 1999 as 'a framework promoting peace, stability, freedom and economic prosperity' (European Commission, 2016) confirming it further at the Thessaloniki summit in 2003 as the principal policy mechanism towards this region, the countries of which could expect to the EU (see the Introduction to this issue). Shortly after its reaffirmation in 2003, SAP was seen in academic circles as an unequivocal sign of the EU's long-term objective to expand south-eastwards in the future (Pippan, 2004, p. 220).

Against the backdrop of the SAP's introduction and in the context of historical changes in Serbia with the regime-change taking place in October 2000, over one hundred civil society organisations met in Zagreb a month later. They discussed how best to advance the common goal of regional cooperation between Croatia, Bosnia-Herzegovina and Serbia and Montenegro within rump Yugoslavia. This was the first major regional attempt to open up frank discussions about the re-start of political, economic and cultural cooperation between these three former wartime foes, which all individually sought the EU as their principal foreign policy and trade partner. At the second session of this conference the following year in Novi Sad, a so-called umbrella of the Igman Initiative was established with four coordinating centres (Igman Initiative, 2018a). For Serbia, the civil society association responsible for coordination, confidence-building measures and advocacy was the Centre for Regionalism, originally founded in 1998 to deal with issues such as local government reform, democratisation, minority rights and regional integration.

The Centre for Regionalism, as part of its work within the Igman Initiative, was involved in research and lobbying activities on the topic of the $20^{\text {th }}$ anniversary of the Dayton Peace Accords. Civil society organisations from across the four countries, with 
the Centre for Regionalism as the coordinating body for Serbian NGOs and experts, were engaged in opening the dialogue on some key outstanding questions following the conclusion of the Dayton Peace Accords (such as the decentralisation of BosniaHerzegovina as a 'precondition for regional peace and stability') (Centre for Regionalism, 2016). They successfully lobbied national governments and relevant ministries to get involved in their work. For example, the EU's Enlargement Department tasked the Igman Initiative to implement a project which was to find recommendations for practical solutions to citizens' status and outstanding property issues in the signatory states to the Dayton Agreement. They lobbied national governments and got experts from relevant ministries in all four countries to be closely involved in research and policy recommendations components of this project (Igman Initiative, 2018b). The Igman Initiative's civil society efforts also focused on improving the EU accession process across the region, in particular following Croatia's successful accession in July 2013.

In Serbia, the Centre for Regionalism implemented further important initiatives some connected to the Igman Initiative's goals but also stand-alone projects, which were financed either by EU agencies or larger civil society organisations, all of which are listed on their website (Centre for Regionalism, no date). These projects included the establishment of a dialogue mechanism with civil society organisations from Kosovo to promote good neighbourly relations, and research and lobbying efforts involving Roma people (which was at times a topic of contention between Serbia and the European Union). A key project on Kosovo included monitoring of an agreement between Belgrade and Pristina on the free movement of goods and people in the context of regional cooperation (Centre for Regionalism, 2013). In terms of advocacy for the Roma people, the Centre for Regionalism as part of the Igman Initiative has advocated and lobbied for the Serbian Government to recognise the special needs of the internally-displaced Roma people as a special category of displacement. This NGOs is involved in the Igman Initiative's civil monitoring of rights and interests of the Roma people across Serbia, including their representation to the Serbian Government and regional bodies (Centre for Regionalism, 2015). The Roma people are characterised as a special vulnerable category who often lack personal documentation and access to clean and safe living conditions. As the Igman Initiative aims to promote the EU's national integration guidelines for inclusion of the Roma people, the Centre for Regionalism in Serbia has been an indispensable local implementing body of this framework, aimed at changing and improving regional relations towards the common goal of EU accession for all remaining candidates in Southeast Europe (European Union Agency for Fundamental Rights, 2018). 


\section{Civil society as a forum for resolution of bilateral issues with EU members}

Since the wars of the Yugoslav disintegration in the 1990s, there has been an increasing trend of internationalising Serbia's domestic issues and of nationalising Serbian foreign policy, which is also evident through the work of civil society organisations. This means that issues that would traditionally be excluded from the mainstream European accession processes, or resolved in a bilateral setting have presented serious obstacles to or delays in Serbia's accession. One such issue occurred in 2013, when a bilateral issue between Serbia and Lithuania regarding a position of a Lithuanian business entity in Serbia delayed Serbia's association agreement with the EU (Čpajak, 2012). Since the 1990s, Romania has repeatedly questioned the position of a Romanian minority in Serbia, the Vlachs (who are also divided amongst themselves whether they are affiliated with Romania or a stand-alone ethnic group). Romania does not recognise the existence of a separate Vlach community and language, considering it a variant of Romanian. Serbia, however, regards Vlachs as a distinct entity, as 35339 Serbian residents in the 2011 Census identified specifically as Vlachs whereas 29332 residents identified as Romanian (Čotrić, 2015).

In 2012, Romania delayed giving Serbia an EU candidacy status because of the Vlach question, causing sharp criticism by other EU member states, in particular from Germany (Tanjug, 2012). Pro-EU NGOs in Serbia have been, since this incident, more active on this front in order to contribute through informal diplomacy (the so-called second track diplomacy), applied research and dialogue process to the resolution of such contentious issues. In mid-2016, the Forum for Ethnic Relations, which has existed for over thirty years, organised a roundtable on Serbian-Romanian relations, Serbia's EU accession and the position of a Romanian ethnic minority in Serbia, with selected participants and representatives, inviting both Vlach and Romanian representatives (Forum for Ethnic Relations, 2016). As a background, this NGO was formed by European and North American academics in 1989, but registered formally as an NGO in Belgrade in 1991; it was anti-war, anti-nationalist and multicultural in character. Their Serbian-Romanian roundtable in mid-2016 was one of four such encounters organised with support from the Embassy of the United Kingdom in Serbia and the Foundation for an Open Society, each of which focused on improving bilateral relations between Serbia and its neighbours (Bulgaria, Romania, Croatia and Hungary), resolving ethnic minority questions and speeding up Serbia's EU accession. Its ongoing monitoring work in these thematic areas has provided a unique avenue for further dialogue, confidence-building measures and discussion which did not exist before in such a format between Serbia and its EU neighbours.

Another NGO, the International and Security Affairs Centre (ISAC) Fund, contributed to the ongoing monitoring of this issue through applied research. It published a comprehensive, chronological study of Serbia-Romania relations since the early $20^{\text {th }}$ century, which was supported by the funds provided by the Royal Norwegian embassy. The study offers a detailed list of recommendations to the Serbian Government on required legislative and other changes that could further improve inter- and intraethnic relations between Romanian and Vlach communities. It also specifically urges the Romanian Government not to use the EU accession process to exert pressure on Serbia on issues that are of a strictly bilateral nature (ISAC Fund, 2015, p. 49). This NGO also published a policy-oriented research paper, which puts into a wider perspective contemporary Serbian-Romanian relations and how a bilateral dispute 
between an EU member and a non-EU member can seriously weaken, threaten or delay accession for EU candidates (Novakovic and Djurdjevic, 2015).

\section{The watchdog of LGBT rights}

In the Serbian case of EU accession, a notable example of the area of human rights where civil society has played a crucial role is the advancement and a watchdog of rights for the LGBT community (Bilic, 2016). After Serbia's regime-change, the attempt to hold the 'first Yugoslav gay parade' was quashed by representatives from far-right organisations in Serbia (B92, 2001). Democratic Serbia came under international spotlight for a Pride parade going disastrously wrong in June 2001. Taking place after a major national soccer match, football hooligans attacked the Pride parade guarded by security forces, with many participants, journalists and members of the police force sustaining significant injuries. As a consequence, the Serbian Government was reluctant to allow the Pride Parade to take place for a number of years. As an expression of solidarity, EU Ambassador to Serbia Vincent Degart personally spoke at the opening of the next parade, which took place in 2010. He was supported by other members of the EU's diplomatic community in Serbia (Associated Press, 2010). The pride parade was again banned in 2011 by Serbia's National Security Council, which was reported on with regret by the European Parliament's Intergroup on LGBT rights. The European Parliament stated at the time that 'the European Parliament will take note of [that] weekend's events in its upcoming accession report for Serbia, planned for early 2012' (The European Parliament's Intergroup on LGBT rights 2011). From 2014 onwards, the Pride parade was successfully held in Serbia every year (Gould and Moe, 2015). This topic always resurfaces in the European Union's annual reports on Serbia's accession (Ejdus and Bozovic, 2016).

An activist lesbian association Labris has, since 1995, fulfilled the role of civil society's advocacy on social inclusion of LGBT people primarily through public education campaigns and watchdog activities. Labris started as a lesbian newspaper in 1995, evolving to a major national LGBT rights advocacy group. In 2015-16, they found that at least nine major school textbooks (many of which were over 30 years old and still in use) had material which was offensive to the LGBT community. Following this finding, they lobbied Serbia's Education Ministry to remove such material from textbooks. So far, some of these textbooks have been altered in response to this public campaign. Labris also noted that while Serbia nowadays has many laws that guarantee the rights of the LGBT community, the political will and capacity to change things in practice is much slower (Labris, 2017). In 2017, Labris and other LGBT activists welcomed as a historic move the unexpected decision by a rather conservative politician, President Aleksandar Vucic, to appoint as Serbia's Prime Minister an openly lesbian person (Gej Strejt Alijansa, 2016). Ana Brnabic, a political newcomer, was first appointed as a Minister in the Vucic Government in 2016, making history for the LGBT community in Serbia. She was the first lesbian Prime Minister in the region to ever be appointed. Alongside other activist associations, Labris contributed to the formation of a monitoring mechanism for reporting hate crimes and attacks against members of the LGBT community in Serbia, as reported to the European Commission in the context of Serbia's accession progress report (ILGA-Europe, 2016). 


\section{Protection of freedom of speech and EU advocacy role}

A key task for Serbia's civil society has been the dissemination of factual information about the EU, whose image was tarnished during many years of authoritarianism and the Milosevic-era propaganda machinery (National Convention on European Union, 2014b). In May 2008, for instance, nationalist posters were placed in Belgrade opposing Serbia's then President Boris Tadic and the Serbian Government for having signed the Stabilisation and Association Agreement (SAA) on a closer relationship with the EU (Pejic, 2010). There arealso recorded cases where the so-called pro-patriotic NGOs (sometimes bordering on being extremist right or leftist groups such as Group 1389), directly lobbied against Serbia's EU orientation through anti-EU public campaigns and by labelling pro-EU NGOs as anti-Serbian and foreign agents, and even by physically threatening the staff working for these NGOs, pro-Western journalists and political commentators (Zivanovic, 2017). This 'uncivil' side of civil society in Serbia has not been discussed here at length, but it is important to factor it in when discussing obstacles to Serbia's EU accession and the work of civil society towards this goal (Cabric, 2013). Civil society in Serbia has been a counter-force to those negative, anti-democratic and populist forces (that are also strongly anti-EU in character) by further advancing a liberal democratic agenda and promoting civic values of tolerance and inclusion (Markovic, 2012, p. 47).

In October 2017, more than 200 civil society organisations and media outlets supported a petition against 'darkness of the media' in Serbia. They highlighted the important role of independent media in democratic societies, and advocated for more transparency and media freedoms in Serbia which they claim had been seriously eroded (The Network of the Committees of Human Rights in Serbia, 2017). According to Freedom House reports, Serbia's press freedom worsened over the past decade as a result of slow implementation of legal protections and the enactment of new regulations which have increased government control over the media (Freedom House, 2018). The European Commission, in its latest progress report on Serbia, has also highlighted that Serbia needs to improve in the area of media and press freedoms such as by improving monitoring of broadcasters, adopting legislation of cyber security and media literacy as part of the education system more broadly (European Commission, 2018a). In this sense, civil society has been very active, but the Serbian Government has been slow to respond to recommendations and policy reports, the consequences of which are felt in criticisms of this issue world-wide, including from UN officials (Balkan Insight, 2017).

\section{Conclusions}

This paper has examined the multiple roles that civil society actors in Serbia have played in the process of this country's democratic transition from authoritarianism to democracy. These roles have included the maintenance of oppositional political discourses during the Milosevic era in Serbian politics; the watchdog/monitoring role over key areas of reform; the role of a dialogue partner of the Serbian Government on various topics regarding EU accession; the EU advocacy role, the role of an advocate for better protection of human and minority rights, better neighbourly relations and media freedoms. Pro-EU civil society associations acted as the main bridge of communication and contact between Serbian society at large and EU institutions during the times of the country's international isolation, sanctions and economic pressure placed on the Serbian Government in the 1990s and 2000. Institutional links 
developed between the main EU institutions and Serbian NGOs during that era have been the foundation for further development of Serbia's non-government sector and deeper intra-civil society cooperation, including on projects with high visibility such as the Belgrade Security Forum, the Igman Initiative and the LGBT human rights watch network that was set up by Labris and similar organisations.

This paper used illustrative case studies of specific NGO activities to highlight some of civil society's achievements in Serbia's EU accession process. In February 2018, the European Commission published a roadmap for further enlargement and a possible inclusion year for new members - 2025 (see Petrovic's Introduction to this issue). The Commission specifically mentioned civil society as part of the political, economic and social transformation of the Western Balkans (European Commission, 2018b). Viable, protected and independent civil society is vitally important for Serbia's accession process to continue, and for Serbia to join the EU family in the foreseeable future.

However, significant obstacles to the work of civil society in Serbia remain. Key challenges include the long-term viability of funding, protection from anti-democratic forces and the need to preserve independence in civil society's work vis-à-vis all other actors, as well as donors which include the Serbian Government. Civil society can only act as a counter-force to populist groups and narratives in Serbia if its activists are operating in a safe space where their freedom of speech is upheld in both theory and practice. One of the major tasks for pro-EU civil society in Serbia is to continue with its EU advocacy efforts, as public opinion globally and in Serbia too has turned more Eurosceptic. For a country that is still undergoing transformation and that has progressed enormously from being Europe's pariah in the 1990 s to an open and progressive democratic state by 2018 (despite many ongoing challenges which all postCommunist countries face to one degree or another) it is imperative to continue to recognise, support and protect the work of Serbian civil society as a precondition for both democracy and EU membership.

\section{Bibliography}

Amnesty International, 1992, 'World report 1992: Yugoslavia', accessed on 1 May 2018, https://www.amnesty.org/download/Documents/POL1000011992-ENGLISH.PDF.

Associated Press, 'Serbia police clash with far-right rioters at gay pride march', Guardian, 11 October 2010, https://www.theguardian.com/world/2010/oct/10/serbia-police-rioters-gay-pride.

Balkan Insight, 2017, 'New media freedom campaign launched in Serbia ', 5 October. Accessed on 1 May 2018, http://www.balkaninsight.com/en/article/serbianjournalists-and-ngos-set-up-new-campaign-for-media-freedom-10-05-2017.

British Broadcasting Corporation (BBC), 2011, 'Milosevic extradited', 28 June 2001, accessed on 1 May 2018, http://news.bbc.co.uk/2/hi/europe/1412828.stm.

Belgrade City Council, 2018, 'Disintegration years 1988-2000', accessed on 1 May 2018, http://www.beograd.rs/index.php?lang=cir\&kat=beoinfo\&sub=201267\%3f.

Belgrade Security Forum, 2018, 'About organisers', accessed on 1 May 2018, http://www.belgradeforum.org/about-organisers. 
Beta, 2002, 'Djindjić: Civilno društvo i uslov i cilj razvoja', accessed on 1 May 2018, http://www.msp.rs/Srpski/Bilteni/Srpski/b140602_s.html.

Bilic Bojan (ed.), 2016, LGBT Activism and Europeanisation in the post-Yugoslav space: on the rainbow way to Europe, Palgrave, London.

Brandt, Martin, 2011, 'Serbia: The Legacy of Otpor', Deutsche Welle, accessed on 1 May 2018, http://www.dw.com/en/serbia-the-legacy-of-otpor/av-6449528.

B92, 2018, 'Silom prekinuta gej parada u Beogradu', 30 June 2001, accessed on 1 May 2018, https://www.b92.net/info/vesti/index.php?yyyy=2001\&mm=06\&dd$=30 \& n a v \_$category=1\&nav_id=27332.

Cabric, Nemanja, 2013, 'Serbia's right-wingers dream of nationalist resurgence', Balkan Transitional Justice, 20 May 2013, accessed on 1 May 2018, http://www.balkaninsight.com/en/article/serbia-s-right-wingers-dream-ofnationalist-resurgence.

Centre for Regionalism, no date, 'Donatori', http://www.centarzaregionalizam.org.rs/html/srp/donatori.html.

Centre for Regionalism, 2016, 'Projekti: 20 godina nakon dejtonskog sporazuma', accessed on 1 May 2018, http://www.centarzaregionalizam.org.rs/html/srp/projekti/projekti22.html.

Centre for Regionalism, multiple authors, September 2013, 'Monitoring implementacije dogovora izmedju Kosova i Srbije u oblasti slobode kretanja ljudi i robe', accessed on 1 May 2018, http://www.centarzaregionalizam.org.rs/prilozi/monitoring/Monitoring_SRB.pdf.

Centre for Regionalism, multiple authors, November 2015, 'Civilni monitoring u okviru projekta Zastupanje interesa Roma u okviru Sarajevskog procesa stambenog zbrinjavanja', accessed on 1 May 2018, http://www.centarzaregionalizam.org.rs/prilozi/Zastupanje_interesa_Roma_u_okviru_Sarajevskog_procesa_stambe nog_zbrinjavanja.pdf.

Cevallos, Albert. 6 August 2001, Whither the Bulldozer? Nonviolent Revolution and the Transition to Democracy in Serbia. Special report of the United States Institute of Peace, Washington D.C., accessed on 1 May 2018, https://www.usip.org/publications/2001/o8/whither-bulldozer-nonviolent-revolution-and-transitiondemocracy-serbia.

Civic Initiatives, 2018, 'About us', accessed on 1 May 2018, https://www.gradjanske.org/o-nama/.

Civic Initiatives, 2016, 'In Memoriam: Miljenko Dereta', 3 November, accessed on 1 May 2018, http://www.gradjanske.org/en/in-memoriam-miljenko-dereta-2/.

Čpajak, P., 2018, 'Jedino Litvanija nije ratifikovala SSP', Politika, 20 April 2012, accessed on 1 May, http://www.politika.rs/sr/clanak/215930/Jedino-Litvanija-nijeratifikovala-SSP. 
Čotrić, Aleksandar 2018, 'Vlaško pitanje, problem u odnosima Srbije i Rumunije', Politika, 1 December 2015, accessed on 1 May 2018, http://www.politika.rs/sr/clanak/344434/Pogledi/Vlasko-pitanje-problem-uodnosima-Srbije-i-Rumunije.

Djukić, Slavoljub. 2001, Milosevic and Markovic: A Lust for Power, McGill-Queen's University Press, Canada.

Ejdus Filip and Bozovic, Mina. 2016, 'Europeanisation and indirect resistance: Serbian police and Pride Parades', The International Journal of Human Rights, no page numbers provided.

Engelberg, Stephen. 2018, 'Protests by the Serbs widen in Belgrade', The New York Times, 12 March 1991, accessed on 1 May 2018, https://www.nytimes.com/1991/o3/12/world/protests-by-the-serbs-widen-inbelgrade.html.

EUR-LEX, 2012, 'Consolidated versions of the Treaty on European Union and the Treaty on the Functioning of the European Union', accessed on 1 May 2018, http://eurlex.europa.eu/legal-content/EN/TXT/HTML/?uri=CELEX:12012M/TXT\&from=EN.

EUR-LEX, 2007, 'European initiative for democracy and human rights (EIDHR) (2000-2006)', accessed on 1 July 2018, https://eur-lex.europa.eu/legalcontent/EN/TXT/?uri=LEGISSUM:r10110.

European Movement International, 2018, accessed on 1 May 2018, http://europeanmovement.eu/.

European Commission, 2016, 'Stabilisation and association process', accessed on 1 May 2018, https://ec.europa.eu/neighbourhood-enlargement/policy/glossary/terms/sap_en.

European Commission, 2018a, 'Serbia 2018 report', 17 April 2018, pp. 62-63, accessed on 1 May 2018, https://ec.europa.eu/neighbourhoodenlargement/sites/near/files/20180417-serbia-report.pdf.

European Commission 2018b, 'A credible enlargement perspective for and enhanced EU engagement with the Western Balkans', 6 February 2018, accessed on 1 May 2018, https://eeas.europa.eu/sites/eeas/files/communication-credible-enlargementperspective-western-balkans_en.pdf.

European Parliament, 2000, 'Santa Maria de Feira European Council: Presidency Conclusions', 19-20 June 2000, accessed on 1 May 2018, http://www.europarl.europa.eu/summits/fei1_en.htm\#V.

EU delegation in Serbia, 2018, 'European Instrument for Democracy and Human Rights (EIDHR)', accessed on 1 May 2018, https://europa.rs/pomoc-republicisrbiji/eidhr/.

European Union Agency for Fundamental Rights, 2018, 'Roma', accessed on 1 May 2018, http://fra.europa.eu/en/theme/roma. 
Evropski Pokret u Srbiji, 2018a, 'O nama', accessed on 1 May 2018, http://www.emins.rs/sr/onama/index.html.

Evropski Pokret u Srbiji, 2018b, 'Aktivnosti', accessed on 1 May 2018, http://www.emins.rs/sr/aktivnosti/projekti/index.html.

Forum for Ethnic Relations, 2016, 'Okrugli sto na temu bilateralni odnosi Srbije i Rumunije: manjinska politika i integracije', 15 June, accessed on 1 May 2018, http://fer.org.rs/okrugli-sto-na-temu-bilateralni-odnosi-srbije-i-rumunijemanjinska-politika-i-evropske-integracije/.

Freedom House, 2017, 'Freedom of the Press 2017', 2018, accessed on 1 May 2018, https://freedomhouse.org/report/freedom-press/freedom-press-2017.

Gace Nadezda i Jovanovic, Jeka, 2016, 'O dijalogu Aleksandra Vucica i Edija Rame na 6. Beogradskom Bezbednosnom Forumu', Novi Magazin, 28 October, accessed on 1 May 2018, http://bfpe.org/1220/.

Gej Strejt Alijansa, 2016, 'GSA pozdravlja imenovanje Ane Brnabic za mandatarku nove vlade Srbije', 16 June, accessed on 1 May 2018, http://gsa.org.rs/2017/o6/gsapozdravlja-imenovanje-ane-brnabic-za-mandatarku-nove-vlade-srbije-2/.

Gellner, Ernest. 1994, The Conditions of Liberty: civil society and its rivals, Penguin, London.

Gradjanske Inicijative, 2017, 'Serbia: country paper', August, accessed on 1 May 2018, http://www.horizont30oo.at/wp-content/uploads/2016/o7/WB_-CountryPaper_Serbia.pdf.

Goati, Vladimir. 2001, Izbori u SRJ 1990-1998. Volja gradjana ili izborna manipulacija (Dodatak 20oo), Centar za Slobodne Izbore i Demokratiju, Belgrade.

Gould John A. and Moe, Edward. 2015, 'Nationalism and the Struggle for LGBTQ Rights in Serbia, 1991-2014', Problems of Post-Communism, Vol. 62, Issue 5, pp. 273286.

Human Rights Watch, 1998, 'International Appeal-Alternative Academic Educational Network (AAEN)', 14 December, accessed on 1 May 2018, https://www.hrw.org/reports/1999/serbia/Serbia99-12.htm.

Human Rights Watch, 2000, 'Curtailing political dissent: Serbia's campaign of violence and harassment against government critics' (12) 6, accessed on 1 May 2018, https://www.hrw.org/reports/2000/serbia/.

Igman Initiative, 2018a, 'History', accessed on 1 May 2018, https://www.igmaninitiative.org/about-us/history/.

Igman Initiative, 2018b, 'Macro projects', accessed on 1 May 2018, http://www.igmaninitiative.org/projects/macro-projects/\#4.

ILGA-Europe, 2016 ,Contribution from Labris, Gay-ten and Da se Zna to Serbia's country 2016 progress report', 9 May, accessed on 1 May 2018, https://www.ilgaeurope.org/sites/default/files/enlargement_review_serbia_2016.pdf. 
Informativna Služba Dveri, 2016, 'Boško Obradovič: migranti, prozapadne NVO i Nebojša Krstić važniji od beba', 6 December, accessed on 1 March 2018, http://dveri.rs/clanci/bosko-obradovic-kzn-migranti-prozapadne-nvo-i-nebojsakrstic-vazniji-od-beba\#cyr.

ISAC Fund, 2015, 'Srpsko-rumunski odnosi i polozaj vlaske nacionalne manjine u Srbiji. Studija prakticne politike', accessed on 1 May 2018, https://www.isacfund.org/download/SR-RU-Odnosi.pdf.

Keman, Hans. 2018, 'Polyarchy', Encyclopaedia Britannica, accessed on 1 March 2018, https://www.britannica.com/topic/polyarchy.

Kostovicova, Denisa.2006, 'Civil society and post-communist democratization: facing a double challenge in post-Milošević Serbia', Journal of Civil Society (2) 1, pp. 21-37.

Kresovic, Tomislav. 2016', Ko je uticao na Srbiju do 2000. godine', Koreni, 18 January, accessed on 1 March 2018, http://www.koreni.rs/ko-je-uticao-na-srbiju-do-200ogodine/.

Kulish, Nicholas. 2010, 'Recasting Serbia's image, starting with a fresh face', The New York Times, 15 January, accessed on 1 March 2018, https://www.nytimes.com/2010/o1/16/world/europe/16jeremic.html.

Kuzio, Taras. (2006), 'Civil society, youth and societal mobilization in democratic revolutions’, Communist and Post-Communist Studies (39) 3, pp. 365-386.

Labris, 2017, 'Education: first step towards social inclusion of LGBT people', 24 October, accessed on 1 March 2018, http://labris.org.rs/en/education-first-steptowards-social-inclusion-lgbt-people.

Lopandić, Duško and Minić, Jelica. 2000, Pripreme za evropsku integraciju, Evropski Pokret u Srbiji, Belgrade.

Markovic, Nina. 2012, 'Civil society in democratic transformation in former Eastern Europe', In Transitions Revisited. Central and Eastern Europe twenty years after the Soviet Union, Eva Polonska-Kimunguyi and Patrick Kimunguyi (eds), Scholar Publishing House, Warsaw, pp. 45-63.

Markovic, Nina. 2014, Political relations between the European Union and Serbia in a broader historical perspective, unpublished doctoral thesis, Australian National University, Canberra.

Media Centre Belgrade, 2011, 'Who are and what are NGOs doing in Serbia', 20 October, accessed on 1 March 2018, http://www.mc.rs/nvo-u-srbiji-ko-su-i-starade.4.html?eventId $=8191$.

National Convention on European Union, 2014a, accessed on 1 March 2018, http://eukonvent.org/radne-grupe/.

National Convention on European Union, 2014b, 'Public opinion polls on the citizen attitudes towards Serbia's European integration processes', accessed on 1 March 2018, 
http://eukonvent.org/istrazivanje-javnog-mnenja-o-stavovima-gradana-o-procesuevropske-integracije-srbije/.

Nikolayenko, Olena. 2013, 'Origins of the movement's strategy: The case of the Serbian youth movement Otpor', International Political Science Review (3/2013), Volume 34, Issue 2, pp. 140-158.

Novakovic Igor and Djurdjevic, Nenad. 2015, 'Serbia and Romania: policy perspectives', ISAC Policy Perspective, accessed on 1 March, https://www.isacfund.org/wp-content/uploads/2017/o3/Srbija-i-Rumunija-Policy-Perspective.pdf.

Obradović-Wochnik, Jelena. 2013, 'Serbian Civil Society as an exclusionary space: NGOs, the public and "coming to terms with the past", In Vesna Bojicic-Dzelilovic, Denisa Kostovicova and James Kerr Lindsay (eds.), Civil Society and Transitions in the Western Balkans, Palgrave Macmillan, London, pp. 210-229.

Office for Cooperation with Civil Society, 2014, 'A three year annual report, 2011-2013', accessed on 15 July 2018, http://civilnodrustvo.gov.rs/upload/documents/Kancelarija/Izvestaji/Izvestaj-o-radu-2011-2013-SR.pdf.

Organization for Economic Cooperation and Development (OECD), 2003, Reviews of National Policies for Education. South Eastern Europe, OECD, France.

Parau, Cristina Elena. 2008, 'Impaling Dracula: how EU accession empowered Civil Society in Romania', West European Politics (32) 1, pp. 119-141.

Pejic, Nenad. 2010, 'Another showdown for the two faces of Serbia', Radio Free Europe, 29 July, accessed on 1 March 2018, https://www.rferl.org/a/Another_Showdown_For_The_Two_Faces_Of_Serbia/2113226.html.

Petrovic, Milenko. 2013, The Democratic transition of post-communist Europe. In the shadow of communist differences and uneven Europeanisation', Palgrave Macmillan, New York.

Pippan, Christian. 2004, 'The rocky road to Europe: the EU's SAP for the Western Balkans and the principle of conditionality', European Foreign Affairs Review, Vol. 9, Issue 2, pp. 219-245.

Popadic, Jelena. 2015, 'Država za NVO godišnje izdvaja koliko i za nauku', Politika, 12 June, accessed on 1 July 2018, http://www.politika.rs/sr/clanak/330139/Drustvo/Drzava-za-NVO-godisnje-izdvaja-koliko-i-za-nauku.

Radio-Television Serbia, 2016, 'Zapadnobalkanska šestorka za brži i lakši ulazak u EU', 30 September, accessed on 1 March 2018, http://www.rts.rs/page/stories/sr/story/11/region/2472054/zapadnobalkanskasestorka-za-brzi-i-laksi-ulazak-u-eu.html.

Radio Free Europe, 1999, 'Serbia: Milosevic's crackdown on universities', Relief Web, 3 February, accessed on 1 March 2018, https://reliefweb.int/report/bosnia-andherzegovina/serbia-milosevics-crackdown-universities. 
Sombutpoonsiri, Janjira. 2012, The use of humour as a vehicle for nonviolent struggle: Serbia's 1996-7 protests and the Otpor (resistance) movement, unpublished $\mathrm{PhD}$ thesis, La Trobe University, http://arrow.latrobe.edu.au:8080/vital/access/manager/Repository/latrobe:34092.

Spoerri, Marlene. 2015, Engineering Revolution: The Paradox of Democracy Promotion in Serbia, University of Pennsylvania Press, Philadelphia.

Tanjug, 2017, 'Evropski pokret pozvao građane da izađu na izbore', Blic, 23 March, accessed on 1 March 2018, https://www.blic.rs/vesti/politika/evropski-pokretpozvao-gradane-da-izadu-na-izbore/nsdbgq7.

Tanjug, 2012, 'Rumunija odlaže odluku o Srbiji', 28 February, accessed on 1 March 2018, https://www.b92.net/info/vesti/index.php?yyyy $=2012 \& \mathrm{~mm}=02 \& d d=28 \& n a v-$ _category $=1262 \&$ nav_id $=586205$.

Telegraf, 2015, 'Vučić oči u oči sa NVO: vlada je spremna na predloge i kritike civilnog društva', 14 May, accessed on 1 May 2018, http://www.telegraf.rs/vesti/politika/1567204-vucic-oci-u-oci-sa-nvo-vlada-je-spremna-na-predloge-ikritike-civilnog-drustva.

The European Parliament's Intergroup on LGBT rights, 2011, 'Belgrade Pride banned: Members of the European Parliament express deep regret', 30 September, accessed on 15 April 2018, http://www.lgbt-ep.eu/press-releases/belgrade-pride-banned-mepsexpress-deep-regret/.

The Network of the Committees of Human Rights in Serbia, 2017, 'Potpisan proglas za slobodu medija', 5 October, accessed on 15 April 2018, http://chrisnetwork.org/2017/10/potpisan-proglas-za-slobodu-medija/.

The Washington Post, 1988, 'Serbs rally in Belgrade over Kosovo', 20 November, accessed on 15 April 2018, https://www.washingtonpost.com/archive/politics/1988/11/20/serbs-rally-in-belgrade-over-kosovo/18a54f286f6b-4c2d-9907-odb69d9532c8/?utm_term=.0578cfe9784e.

United Nations, 2000, 'Security Council recommends Federal Republic of Yugoslavia for membership of United Nations', press release SC/6944, 31 October, accessed on 15 April 2018, https://www.un.org/press/en/2000/20001031.sc6944.doc.html.

Uvalic, Milica. 2010, Serbia's transition. Towards a better future, Palgrave Macmillan, New York.

Versteeg, Lia C.R.M. 2011, 'Civil Society under the Treaty of Lisbon: relationship between national public benefit organizations and European Union policy?', Nonprofit Policy Forum (2), 2, article 4.

Virtuelni Muzej Zorana Đinđića, 2012, accessed on 1 March 2018, http://www.zorandjindjic.org/citati.

Voicu Bogdan and Voicu, Malina. 'Volunteers and volunteering in Central and Eastern Europe', Sociológia (41) 6, pp. 539-63. 
Vujadinović, Dragica. 2009, Civilno društvo i političke institucije. Srbija u vrtlogu promena, Faculty of Law at the University of Belgrade, Serbia.

Wunsch, Natasha. 2015, 'Beyond instrumentalisation: NGO monitoring coalitions in Croatia, Montenegro, and Serbia', East European Politics, Vol. 25, Issue 4, pp. 452467.

Zivanovic, Maja. 2017, 'Anti-EU tide is rising in Serbia, NGO warns', Balkan Insight, 9 February, accessed on 1 March 2018, http://www.balkaninsight.com/en/article/governments-anti-eu-rhetoric-affects-serbian-citizens-02-07-2017. 